\title{
TECNOLOGIAS E MEIOS COMUNICACIONAIS NA EDUCAÇÃO: A NECESSÁRIA REFLEXÃO SOBRE FORMAÇÃO E TRABALHO DOCENTE
}

\author{
Maria José Dozza Subtil ${ }^{1}$
}

\section{RESUMO}

O texto apresenta reflexões sobre tecnologias, formação e trabalho docente na perspectiva marxista que remete os objetos de estudo às relações mais amplas da sociedade capitalista, sem descurar da dimensão dialética entre a materialidade econômica e as ideias produzidas em tempos e espaços históricos. Analisam-se os conceitos de tecnologias/meios comunicacionais relacionando-os aos processos cognitivos, à formação e ao trabalho docente problematizando essas relações na perspectiva ontológica da educação. Fazendo uso da categoria contradição trazemos autores de diferentes perspectivas teóricas que contribuem para a explicitação dos imperativos tecnológicos no contexto educacional. Enfatizamos a relação entre as tecnologias e as respectivas ecologias cognitivas da oralidade, escrita e rede como condição para a efetiva inclusão da maioria dos alunos e professores no universo da cultura digital e do conhecimento universal.

Palavras-chave: tecnologias educacionais; formação docente; trabalho docente; ecologias cognitivas.

\section{TECHNOLOGY AND COMMUNICATION MEANS IN EDUCATION: THE NECESSARY REFLEXION ON QUALIFICATION AND TEACHER WORK.}

\begin{abstract}
This text presents reflections on technologies, qualification and teacher work under the Marxist perspective which links the objects of study to broader relations in the capitalist society, without disregard to the dialectic dimension between the economic materiality and the ideas produced in historical times and spaces. The concepts of technology/communication means are analyzed relating them to the cognitive processes, to qualification and teacher work problematizing such relations in the ontological perspective of education. Employing the contradiction category, authors with different theoretical perspectives are brought to contribute to the explanation of technological imperatives in the educational context. The relation between technologies and the respective cognitive ecology of orality, writing and networks as a condition for the effective inclusion of most students and teachers in the world of digital culture and universal knowledge are emphasized.
\end{abstract}

Keywords: educational technologies, teacher qualification, teacher work, cognitive ecologies.

\section{INTRODUÇÃO}

Subtil (2011) embasada em Canclini (2008), afirma que ler (um texto), assistir (a televisão) e navegar (na internet) não são mais atividades distintas, separadas e estanques. Essas ações se entrecruzam e redefinem o que é ser leitor, espectador e internauta. Aproximando essas constatações ao campo educacional é possível dizer que as operações 
intelectuais envolvidas nesses processos particularmente a oralidade e a escrita são condicionadas e condicionantes dos usos e ambientes cognitivos propostos pelas tecnologias digitais contemporâneas. ${ }^{2}$

Dessa forma, parece consenso hoje dizer que as tecnologias digitais estão há mais de duas décadas integradas e incorporadas às práticas de estudo, lazer, comunicação e ao consumo de modo geral. Importa ressalvar que isso não acontece da mesma forma e na mesma dimensão para todos, na sociedade capitalista, dividida em classes antagônicas. No Brasil, ainda há exclusão aos produtos mais sofisticados e às possibilidades quase ilimitadas de fruição na WEB. De todo modo é possível supor que os professores, em sua maioria jovens usuários da internet e consumidores dos produtos virtuais, estão inseridos no universo globalizado das tecnologias. Essa relativa naturalização e integração aos diferentes modos de uso não significa conhecimento embasado sobre as tecnologias, seus fundamentos, possibilidades e limites, em especial no que tange à educação.

Por esse motivo, refletir sobre trabalho docente e tecnologias significa tomar distância, debruçar-se sobre o tema, retornar a esses objetos e modos de fazer que estão presentes nas relações pedagógicas - presenciais e a distancia - , são históricos e sociais. Para além da dimensão educacional, importa considerá-los como insumos fundamentais no mundo do trabalho na perspectiva do desenvolvimento e da acumulação capitalista em sua fase mais avançada tecnologicamente mas contraditoriamente mais perversa na exploração do trabalho e da natureza. Entendemos que as tecnologias devem ser devidamente equacionadas em sua materialidade como mediações entre pessoas, máquinas, conhecimentos e modos de fazer tanto na sociedade quanto na escola mas também como tributárias de um poder simbólico que em última instância reforçam a dominação de classe pela detenção do capital econômico.

Nessa perspectiva crítica, nos apropriamos de Duarte (2001) que fala das ilusões do "aprender a aprender" inerentes aos tangenciamentos entre pedagogia e "Sociedade do conhecimento" para afirmar categoricamente que tanto os conhecimentos quanto as tecnologias não prescindem das mediações de processos cognitivos e sociais ( relações entre professores e alunos), fundantes a nosso ver da verdadeira relação pedagógica.

Assim, a reflexão que se apresenta é aqui compreendida em seu sentido radical, como movimento de volta ao objeto do pensamento para conhecer, indagar, inquirir. É a partir dessa premissa que o ser humano (sujeito) pode olhar o mundo (e a si mesmo) de fora e propor-se a operá-lo praticamente, moldando-o às suas necessidades. (MACARIO, 2001, p.3).

No percurso de re-fletir sobre tecnologias e meios de comunicação, formação e trabalho docente retomamos neste texto alguns autores, conceitos e idéias que reforçam o princípio da não neutralidade desses objetos e do próprio processo comunicacional. Segundo Baumgarten (2006, p.291), as tecnologias não são somente os artefatos mas referem-se à "[...] infra-estrutura à qual estão integradas e (são) também tecnologias sociais , tais como a administração da produção e dos recursos materiais e humanos". A autora diz que elas são objetivas, "tangíveis" incorporadas ( nos equipamentos) mas se apresentam também "[...] sob a forma intangível de habilidades e práticas". Veremos isso com mais vagar com a ideia de "tecnologias cognitivas" de Pierre Lévy (1993). Esclarecemos que todos os autores, independentemente de suas singulares filiações teóricas, são tomados na dimensão de esclarecimento do objeto enfocado (tecnologias/meios educacionais) pretendendo-se ao mesmo tempo afirmar convicções próprias do marxismo quanto às possibilidades e limites da formação e da humanização no horizonte da sociabilidade capitalista em qualquer esfera da ação humana. 
Belloni (1992) diz da necessidade de investir na formação de professores e alunos num duplo sentido: formar com as tecnologias e para o uso crítico e criativo das tecnologias conhecendo-as em sua gênese histórica e social, compreendendo sua função, o que veiculam e a que projeto de sociedade remetem. Ferrés (1998, p.133), tece considerações nessa mesma direção:

[...] a pedagogia dos meios terá como objetivo oferecer pautas para uma análise crítica dos meios de comunicação de massas áudio visuais [...] . A pedagogia com os meios terá como objetivo incorporar de maneira adequada todos aqueles meios, técnicas e recursos que sirvam para potencializar a aprendizagem; entre eles, os próprios meios de massas audiovisuais $^{3}$

Iniciamos com a explicitação das tecnologias como decorrentes de um processo mais amplo que decorre das mudanças no mundo do trabalho e enfocamos a perspectiva ontológica da educação e os imperativos tecnológicos. Trazendo a discussão para o campo específico dos processos educativos elencamos as idéias de Pierre Lévy sobre as tecnologias intelectuais que historicamente produzem ecologias e artefatos diferenciados na educação. Refletimos sobre as injunções das tecnologias como condicionantes e determinantes na formação de professores e na atuação docente tendo em vista os processos de inclusão excludente que caracterizam as relações entre sujeitos e tecnologias/meios digitais, particularmente os mais pobres.

\section{1 - Reflexões sobre trabalho, tecnologias e formação no mundo contemporâneo}

A partir da última década do século $\mathrm{XX}$ as mudanças radicais no mundo do trabalho decorrentes de uma nova fase do capitalismo, demandaram a inserção de tecnologias de informação e comunicação em todos os níveis de sociabilidade: economia, trabalho, cultura, arte e educação.

$\mathrm{Na}$ gênese do capitalismo a transição do artesanato independente a trabalho assalariado significou a separação absoluta entre produtor e produto. A divisão manufatureira do trabalho significou a decomposição e a parcelarização do processo produtivo. Nesse sentido, sua otimização se deu com a introdução da maquinaria, do taylorismo e do fordismo que, ao compartimentar, mecanizar e sistematizar racionalmente a ação do trabalhador, contribuiu para a sua desqualificação como produtor e o subordinou total e completamente aos mecanismos alienadores da produção capitalista. Hoje esse modelo parece esgotado e surgem novas formas de exploração do trabalho.

Desde meados da década de 80, pelo menos nos países desenvolvidos, apregoa-se a "Lean Production" (produção enxuta) ou "Toyotismo" que

[...] implode os critérios clássicos do fordismo: organização do trabalho rígida e autoritária em troca de um salário mais elevado e de maior tempo livre. O novo comportamento [...] orienta-se pelo consentimento e pela participação; os processos de aprimoramento estão integrados num processo de aprendizagem cooperativa que abrange todos os que fazem parte da empresa... a organização do trabalho deve eliminar a hierarquia e a divisão taylorista, passando a favorecer, por meio da cooperação dócil, grupos de trabalho e teams. ( MARKERT, 1994, p.365).

Nessa perspectiva o trabalhador deve ser formado para assumir várias funções, uma vez que desaparecem as relações hierarquizadas, de modo a otimizar o processo de 
produção/acumulação agora considerado como parte do seu "ser". Ideologicamente é ampliada a ideia de formação para o trabalho uma vez que "O trabalho real necessita mobilizar competências oriundas dos saberes, do saber fazer $e$ do saber ser. (ROSENFIELD; NARDI, 2006, p.63, grifos nossos). Disso decorre que os insumos tecnológicos - como artefatos, conhecimentos ou processos - provocaram mudanças substanciais no mundo do trabalho e na própria sociabilidade capitalista. Baumgarten, (2006, p.288) afirma: "Na sociedade capitalista, tecnologia caracteriza-se por ser um tipo específico de conhecimento, com propriedades que o tornam apto a, uma vez aplicado ao capital, imprimir determinado ritmo à sua valorização".

$\mathrm{Na}$ produção e disseminação das tecnologias de informação e comunicação, especialmente as digitais, revelam-se as interações contraditórias e complexas entre base econômica e superestrutura ideológica. $\mathrm{Na}$ perspectiva dialética dessas relações há interdependência e reciprocidade entre duas dimensões de que compõe o ser social: a individual e a social. Isso é revelado na subjetivação propiciada pelo uso privado da internet ao mesmo tempo da socialização vivida na WEB. Essas duas dimensões no entanto, em última instância, refletem os fundamentos liberais da sociedade burguesa: consumo e individualismo exacerbados pela mediação de tecnologias que se sofisticam, se renovam em tempos cada vez mais curtos e se tornam mais e mais acessíveis, embora seja necessário relativizar esse acesso num país como o Brasil.

A escola não fica imune a esse debate. Ora, se as demandas do mercado exigem outros conhecimentos e uma nova adequação dos sujeitos à essa realidade, evidentemente a discussão sobre tecnologias, educação e formação adquire visibilidade na esteira das ideias de racionalidade, qualidade e competência. $\mathrm{O}$ enfoque na eficiência e na mudança de comportamentos intraescolares para atingir os níveis de qualidade requeridos pela sociedade econômica neoliberal parece ser a ideia subjacente à essas premissas. De acordo com tal perspectiva, a competência do professor está indissoluvelmente ligada ao uso eficiente das tecnologias de comunicação e informação como mediadoras nos processos educativos. O pano de fundo é a "sociedade do conhecimento", economicamente globalizada e que socializa (aos que possuem acesso) informações em todas as áreas, em tempo real, desconsiderando as barreiras geracionais e mesmo econômicas. Na verdade somos todos consumidores dos produtos virtuais!

Essas ideias são explicitadas nos imperativos legais para a aquisição de suportes didático pedagógicos tecnológicos. Como exemplo as Diretrizes Curriculares Nacionais para os cursos de Pedagogia determinam que o egresso dessa Licenciatura deverá adquirir a habilidade de

VII - relacionar as linguagens dos meios de comunicação à educação, nos processos didático-pedagógicos, demonstrando domínio das tecnologias de informação e comunicação adequadas ao desenvolvimento de aprendizagens significativas (BRASIL, 2006, p.2).

Partindo do pressuposto de que os professores já estão inseridos no mundo das tecnologias digitais, o MEC, através da Secretaria de Educação à Distância instituiu o "Portal do Professor" onde são disponibilizados informações de interesse dos docentes, recursos didático pedagógicos, links para Jornal do professor, conteúdos multimídia, espaço da aula, etc. ${ }^{4}$

No próximo item apresentamos ideias sobre a dimensão ontológica da educação e os imperativos para as tecnologias no trabalho docente. 


\section{2- Dimensão ontológica da educação e imperativos tecnológicos}

Chauí (1999, apud GOULART, 2002, p.105), evocava o esvaziamento e a expropriação do trabalho docente uma vez desaparecida a marca essencial da docência - a formação - em favor da transmissão e adestramento. Isso em contextos de debates e práticas sobre formação de professores nas diferentes instâncias desde a universidade (inicial) até a escola ( em serviço, ou na prática). Nessa perspectiva, o uso de novas tecnologias mais eficientes adquire sentido no treinamento para lidar com as informações e conteúdos que recheiam os currículos tanto dos cursos formadores quanto da educação básica.

Numa visão pessimista é possível dizer que a configuração neotecnicista da educação que investiu na burocratização, na informatização, no apostilamento de conteúdos e na formação para o mercado imediato dota o trabalho docente de uma outra dimensão. Não cabe mais ao professor "articular os eixos epistemológicos às necessidades didático-pedagógicas [...]" A ele ficou restrita a tarefa de "[...] escolha dos materiais didáticos, concebidos como mercadorias para consumo, e a administração do tempo dos alunos". (GERALDI,1993, apud GOULART, p.106).

O deslocamento da dimensão de trabalho - categoria fundante da formação e da práxis para a de atividade docente evidencia o reducionismo desse debate. A perplexidade que perpassa os atores desse processo tem a ver com um contexto mais abrangente que nos faz indagar: qual a especificidade deste trabalho em tempos de tecnologias sofisticadas e autossuficientes na comunicação? Que conteúdos e habilidades são necessários aos professores para ensinar os alunos que frequentam as escolas? A que contextos culturais, sociais e de trabalho se destinam nossos educandos? Enfim, qual o papel social do professor hoje?

É sempre pertinente voltar à ideia inicial da reflexão enfocando o sentido ontológico de meios, tecnologias e mídias. Por mais avanços que tenhamos nesse campo não há como ignorar que a epistemologia das mídias embasa-se no conceito de mediação entre duas pontas: alguém/ alguns x alguém/alguns ( humanos e conhecimentos ) e alguma(s) coisa(s) x alguma(s) coisa(s) (máquinas e conhecimentos) Não existe um lugar vazio entre técnica e humanidade, mas espaços plenos de informações, saberes, fruições estéticas e lúdicas que constituem hoje as ecologias cognitivas onde todos nos movemos. Lembrando também que essas ecologias são permeadas pela dimensão mercadológica e pelas mudanças originadas no mundo do trabalho como vimos anteriormente.

Considerando-se a educação como o ato de produzir direta e intencionalmente em cada indivíduo singular a humanidade que é produzida historicamente pelo conjunto dos homens (SAVIANI, 2000), é importante concebê-la em seu sentido ontológico original de estar a serviço da satisfação das necessidades humanas. Ela é importante mediação nas decisões e nas ações do sujeito na luta pela conquista da liberdade. (MACÁRIO 2001, TASSYGNI, 2004). É nessa perspectiva que podemos equacionar devidamente as tecnologias, meios, mídias e o sentido abrangente da tecnologia educacional.

Esse exercício de reflexão deve reafirmar o que já foi levantado anteriormente, que os docentes são consumidores dos mesmos produtos midiáticos e tecnológicos que os alunos: computadores, celulares, internet, tabletes, músicas, novelas, programas, jogos eletrônicos, etc. Há uma aproximação geracional e esses professores já estão aclimatados ao ambiente cognitivo das tecnologias virtuais. Portanto sua formação deve supor que eles são tributários do mesmo processo de leitura crítica e criativa da realidade que apregoamos para os alunos em todos os graus de ensino. 
Importa ressaltar que as tecnologias (contemporâneas) aqui discutidas não foram criadas para a educação, elas foram prioritariamente destinadas a resolver problemas em outras áreas e depois adaptadas e apropriadas para o uso pedagógico. Assim, na escola elas são "de segunda mão".

Subtil e Belloni (2002, p.50), afirmam que a inserção dos audiovisuais nas relações pedagógicas, implementadas nas décadas de 60/70 no contexto da Lei $\mathrm{n}^{\circ}$ 5.692/71 decorrem de uma importação dessa ideia dos norteamericanos que apregoavam a eficiência dos meios técnicos no ambiente pedagógico. O sucesso do uso de retroprojetores, projetores e filmes educativos no treinamento de pessoas para os trabalhos de guerra comprovavam a eficácia dessa absorção pela educação.

O rádio, a televisão e o cinema desde a sua gênese tem a ver com a comunicação, a fruição estética e artística e evidentemente com o consumo de produtos tal como discutido por Horkheimer e Adorno (1982) com a tese da Indústria cultural. O computador, hoje de uso pessoal e social generalizado, em sua gênese foi criado para calcular (cérebro eletrônico) e para armazenar dados, em particular dos programas e projetos de estado nos Estados Unidos.

Assim cabe indagar: quais tecnologias foram criadas especificamente no sentido estrito da relação pedagógica? Tábuas de escrever, giz, quadros? Aqui a suposição é a de que a especificidade dessa relação em sua essência não exigiu até recentemente pelos menos, artefatos e meios mais sofisticados. A mediação era a própria figura do professor, evidentemente com o aporte dos sentidos dos alunos tal como apregoado desde Comênio em sua Didática Magna. A ideia é interessante na medida em que nos leva a redimensionar tanto essa especificidade quanto o papel efetivo das tecnologias no trabalho docente, na perspectiva ontológica da educação sem a qual não se define claramente a função do professor e o papel dos meios no processo educacional.

Lukácz (1981, p.25-26) reportando-se ao trabalho como categoria definidora do processo de humanização, afirma que

[...] a busca dos meios tem uma dupla função: de um lado evidenciar aquilo que governa os objetos em questão independentemente de toda consciência; de outro lado, descobrir neles aquelas novas conexões, aquelas possíveis funções que, quando postas em movimento, tornam efetivável o fim teleologicamente posto.

No caso aqui discutido - tecnologias/meios e educação - cabe sempre reforçar o fim último da mesma que é elevar o homem (singular) à condição de gênero (universal) socializando os conhecimentos da ciência e da cultura historicamente produzidos e acumulados, proporcionando o exercício da liberdade. Evidentemente tal trabalho requer instrumentos e meios específicos que são a garantia objetiva de continuidade da cultura humana. Daí a importância atribuída por Lukácz, à escolha dos meios no desenvolvimento da generidade humana, tendo em vista a concepção histórico-social na formação dos seres humanos como fundamento ontológico da educação.

É mister considerar que, primariamente, o ato educativo, tal como o temos apresentado - na sua gênese ontológica - é um momento do próprio trabalho. Numa palavra, o próprio ato de objetivação posto pelo trabalho é educativo. Nesse sentido há que ressaltar a particularidade dos instrumentos, meios (tecnologias) desse trabalho para além das discussões sobre os aparatos tecnológicos.

Nesse momento tomamos conceitos de autores que, mesmo não se colocando na perspectiva marxista privilegiada nesta reflexão, desenvolvem ideias sobre processo 
comunicacional, "tecnologias cognitivas" e processos mentais das quais nos apropriamos para afirmar a particularidade do uso dos instrumentos no processo educacional.

\section{3 - A particularidade das tecnologias/meios comunicacionais nos processos educativos}

Mc Luhan (1980), em décadas passadas afirmava "o meio é a mensagem" evidentemente numa perspectiva positiva dos meios, num momento em que a televisão em particular e os audiovisuais de modo geral assumiam o protagonismo na comunicação. Embora possamos considerar sua abordagem excessiva, o que nos importa aqui é que o autor propõe um novo significado aos momentos do processo comunicacional produção circulação e recepção - enfatizando as tecnologias por suas características mediadoras que modificam o emissor, o receptor e a mensagem.

A partir dessa ideia entendemos que, mesmo considerando-se numa perspectiva estrutural a gênese e o desenvolvimento dos objetos tecnológicos a serviço da acumulação e dominação econômica, lidar com as tecnologias disponíveis hoje é pensar que elas não são meros aparatos técnicos mas interferem no conteúdo e na forma como recebemos, produzimos e processamos essas informações em especial nos processos educativos. Aqui é necessário lembrar a obsolescência dos computadores e programas que se renovam em muito pouco tempo, exigindo mais do que o treino para o uso dos equipamentos e o enfoque na técnica ${ }^{5}$. É preciso entender como se processam as operações mentais com o aporte das tecnologias e quais as decorrências para o ensino e as aprendizagens. ${ }^{6}$

Pierre Lévy (1993) traz o conceito de tecnologias da inteligência ou tecnologias cognitivas que criam diferentes ecologias- ambientes educacionais com modos próprios de apropriação do conhecimento e da realidade. Evidentemente que isso está ancorado na estrutura material, e tem como pano de fundo a base econômica que determina as mudanças culturais, sociais, técnicas e científicas.

A primeira "tecnologia" é a da oralidade. Nas palavras do autor:

A oralidade primária remete ao papel das palavras antes que uma sociedade tenha adotado a escrita, a oralidade secundária está relacionada a um estatuto da palavra que é complementar ao da escrita, tal como a conhecemos hoje. Na oralidade primária, a palavra tem como função básica a gestão da memória social [...] Numa sociedade oral primaria quase todo o edifício cultural está fundado sobre a lembrança dos indivíduos. A inteligência nestas sociedades encontra-se muitas vezes identificada com a memória, sobretudo a auditiva. (LÉVY, 1993, p.77).

No contexto da agricultura comunal, modo primitivo de economia a oralidade opera pela repetição e pela memória. "O oral era o canal da comunicação" (LÉVY, 1993, p. 77). Nesse sentido podemos visualizar uma ecologia (ou ambiente cognitivo) que privilegia o circulo ao redor dos anciãos em todos os lugares, na tribo, no sertão e nos lares ouvindo os contos e histórias. Transpondo para outros tempos e espaços, o circulo de carteiras na sala de aula junto ao professor, ou o sofá em frente à televisão, na oralidade secundária. Importa reforçar a tecnologia cognitiva da memória e o sentido privilegiado da audição. Há que considerar a persistência da oralidade primária pois segundo Lévy (1993, p.84) :

Dominamos a maior parte das nossas habilidades observando, imitando, fazendo, e não estudando teoria na escola ou princípios nos livros. Rumores, tradições e conhecimentos empíricos em grande parte passam 
por outros canais que não o impresso ou os meios de comunicação audiovisual.

Essas últimas considerações nos alertam, enquanto educadores para o fato de que a memória e a fala são capacidades humanas que transcendem às tecnologias materiais e como tais devem ser desenvolvidas e estimuladas nos espaços escolares como condição para uma adequada formação dos alunos em tempos de tecnologias "sensoriais".

Em segundo lugar o autor aponta a tecnologia da escrita, momento em que a comunicação humana distancia o emissor do receptor. $O$ objetivo é fixar a oralidade, permanecer no tempo e constituir a dimensão histórica: "O eterno retorno da oralidade foi substituído pelas longas perspectivas da história” (LÉVY, 1993, p.87).

Nos primórdios, havia relação entre a escrita e agricultura uma vez que ela foi inventada separadamente por diferentes povos agrícolas, estabelecendo-se uma semelhança entre o escriba que cava sinais na argila e o agricultor que cava sulcos na terra. Há um tempo entre o plantio e a colheita, da mesma forma que há intervalo entre a emissão e a recepção. "A escrita aposta no tempo". (LÉVY, 1993, p.88). Com a possibilidade de fixar as ideias e permitir a construção de sentidos, a escrita permitiu a reflexão e o nascimento das grandes correntes teóricas.

Mantendo essa discussão em perspectiva, sem determinar o pensamento ocidental às técnicas de impressão e de comunicação pode-se afirmar que "A impressão transformou profundamente o modo de transmissão dos textos [...] e inaugura a época das'tábulas rasas e dos sistemas tanto no plano político quanto no científico e filosófico" (LÉVI, 1993, p.96). Nesse segundo contexto da escrita o capitalismo se afirma com o progresso da ciência e da técnica. $\mathrm{O}$ ambiente cognitivo permitido pela impressão possibilitou avanço nas novas mediações e o implemento da comunicação pública e da cultura de massa

Se na oralidade a metáfora era o círculo agora a linha reta significa a leitura e escrita da esquerda para a direita, de cima para baixo que informa o nosso modo de ler e escrever ocidentais. Nessa nova ecologia cognitiva encontram-se as salas de estudo, as escrivaninhas, carteiras, fileiras, cadernos em posição de leitura para concentração e em especial privilegia-se o sentido da visão.

A terceira tecnologia apresentada pelo autor, a digital tem como metáfora a rede ligada ao advento da informática, dos computadores e de todo o avanço tecnológico da segunda metade século XX . Para ele

A principal tendência neste domínio é a digitalização, que atinge todas as técnicas de comunicação e processamento de informações. Ao progredir, a digitalização conecta no centro de um mesmo tecido eletrônico o cinema, a radiotelevisão, o jornalismo, a edição, a música, as telecomunicações e a informática. (LÈVY, 1993, p.102).

Nós acrescentaríamos - 20 anos após essas considerações -, todas as possibilidades de oralidade, escrita e interações que hoje conectam crianças, jovens e adultos nos chats, facebooks, e-books, celulares de última geração, MP3, 4, 5... etc.

O contexto atual é do capitalismo globalizado, com a superação das fronteiras geográficas, econômicas e culturais o que permite a circulação, em tempo real, de produtos e a interatividade em redes de interfaces aglutinando todas as tecnologias e ecologias intelectuais em grupos ou "cada um na sua". É a individuação e contraditoriamente a publicização do indivíduo. A conexão na rede e a virtualidade permitem as experiências sensoriais totais nos jogos eletrônicos e nos videogames como anunciava Kerckhove (1997). 
Assim, se tomarmos essas ideias não de forma absoluta mas contextualizando-as e recuperando o seu sentido pedagógico podemos afirmar que professores devem se voltar para o estudo dessas tecnologias intelectuais e respectivos ambientes cognitivos para pensar que esses processos mentais, em tese, permanecem, apesar das mudanças tecnológicas. Devem ser considerados em interconexão, ou seja, ler, escrever, ouvir, falar em público ou na rede com propriedade, em diferentes linguagens, com criatividade, fazem parte da formação humana e são o fundamento do projeto educacional.

Também é necessário reforçar que essas tecnologias e modos de pensar não "surgem", mas são produzidas em contextos da materialidade econômica que estabelece a organização geral da sociedade, na perspectiva da relação capital/trabalho crivada pelas diferenças de classe. Nos apropriamos das idéias de Goulart (2002, p.150) que afirma:

[...] não basta tratar a relação pedagógica a partir do processo de comunicação, ou dos polos da produção e da recepção. É preciso situá-los em percursos e sentidos constituídos pelos lugares sociais dos sujeitos (desigualdades e diferenças) bem como pelas condições ( contextuais históricas e de situação) em que são realizadas as mediações.

\section{4 - Tecnologias, formação de professores e inclusão}

Como fundamento da formação de professores trazemos as idéias de Saviani (1995) e Duarte (1998) que defendem a especificidade do ato pedagógico como uma relação de ensino, de transmissão de conhecimentos e de assimilação ativa, e assumem o protagonismo do professor nesse processo. Disso decorre que o instrumento da educação ( processo de humanização), é o conhecimento universal, amplo e interessado e como tal deve ser também apreendido pelos professores em seu processo formativo. O balizamento dessa apreensão está no conhecimento de que a realidade não se mostra à primeira vista e que é necessário remeter os atos educativos ao contexto social e econômico da sociedade capitalista de classes. Nesse sentido o papel das tecnologias/meios educacionais se reveste da contraditoriedade própria dos artefatos criados no mundo do trabalho, do mercado e consumo, e adotados no universo escolar.

Nessa perspectiva as tecnologias são dotadas de um poder simbólico que incluem e ao mesmo tempo excluem grande parte da população, consumidora basicamente de produtos pré selecionados e com a validade vencida, dadas a demandas mercadológicas dos países centrais. A ideia de Indústria Cultural - negue-se aqui o viés não contraditório desse conceito - traz uma visão extremamente negativa das mídias como indutoras hipodérmicas de uma estética reducionista, permeada pelo sentido de diversão (amusement) acrítica e empobrecedora:

Em seus escritos, Adorno e Horkheimer denunciam a mercantilização e a padronização promovidas pela Indústria Cultural e chamam isso de semiformação, algo que nega a emancipação do sujeito pela possibilidade de autodeterminação. No entanto, essa constatação não exclui a possibilidade da efetivação da cidadania, a humanização dos sujeitos, a produção da sensibilidade e o exercício estético, porque aqui entra em campo o processo de educação. ( SUBTIL, 2008, p. 293)

O corolário de uma perspectiva dialética nessa questão é formação e trabalho docente dentro de um projeto educacional que contemple a ideia de superação dessa sociedade e que indague em que medida cada tecnologia e cada modo de fazer está 
atrelado a um adequado projeto de educação e inclusão dos jovens. Entendendo-se que o conceito de inclusão supõe

[...] a ousadia de poder raciocinar por si próprio ao mesmo tempo em que se possui publicamente a liberdade para poder criticar as instituições [...] o exercício dessa incumbência de se fazer uso público da razão implica a benfeitoria da própria sociedade, pois não se restringe ao indivíduo, mas, sim, revela-se fio condutor básico das instituições sociais. (ADORNO, 1986, p.99).

A formação deve fazer com que os sujeitos percebam qual o significado histórico, formal, das tecnologias e respectivos conteúdos veiculados na dimensão social e individual. Nesse sentido cabe mais uma vez resgatar Adorno (1995, p. 121) que declara: "A educação tem sentido unicamente como educação dirigida a uma autorreflexão crítica". Acrescentando mais adiante:

A educação seria impotente e ideológica se ignorasse o objetivo de adaptação e não preparasse os homens para se orientarem no mundo. Porém, ela seria igualmente questionável se ficasse nisso, produzindo nada além [...] de pessoas bem ajustadas, em consequência de que a situação existente se impõe precisamente no que tem de pior (ADORNO, 1995, p. 143).

Importa ao final deste trabalho dizer que a "inclusão via acesso" às tecnologias digitais é uma "quase" realidade. Isso porque em pesquisa realizada com crianças de 9 a 12 anos de escola pública e particular, em fase de analise de dados, a autora deste artigo constatou que há uma universalização de posse de celulares e equivalentes eletrônicos. Registre-se o consumo generalizado dessas tecnologias, entre as crianças tanto de classe média quanto as mais pobres, além da frequência às lanhouses, conhecimento de uso e acesso ao computador e à internet. Ressalte-se particularmente que esse fenômeno se acentuou na última década com a ascensão econômica da parcela historicamente marginalizada da população.

Por outro lado a pesquisa tem evidenciado o empobrecimento da escrita e da expressão falada das crianças da escola pública quando das respostas nos questionários e nas entrevistas, na comparação com as crianças de classe média que além da posse também detém maiores conhecimentos escolares e cultura geral.

Esses dados mostram que há uma inclusão/excludente das crianças mais pobres quando as habilidades cognitivas - tecnologias intelectuais, para lembrar Pierre Lèvy - não são devidamente equacionadas na mesma proporção da posse e uso dos artefatos tecnológicos.

Tal revelação trouxe à pesquisadora a necessidade de refletir neste texto sobre os ambientes tecnológicos e as decorrentes habilidades cognitivas sem as quais torna-se vão falar em usos dos artefatos comunicacionais e midiáticos na formação e no trabalho docente. 


\section{CONSIDERAÇÕES FINAIS}

É evidente hoje a perplexidade tanto em relação às mídias em geral quanto aos conteúdos comunicacionais, sociais e escolares mediados. O desafio primeiro é colocar tecnologias/meios a serviço de uma sociedade mais justa e humanizada. E aí cabe perguntar: quais os conhecimentos válidos socialmente hoje? Quais processos educativos podem dar conta, ainda que de forma incompleta das demandas da formação humana nesta sociedade com imperativos tecnológicos e midiáticos avassaladores? Como a escola pode se apropriar dialeticamente dos artefatos tecnológicos sem descurar das capacidades cognitivas que estão na base de todo o arcabouço didático pedagógico e comunicacional (oralidade, escrita, leitura, memória, experiências digitais)? As tecnologias cognitivas coexistem na rede e se uma delas não for contemplada há uma exclusão parcial.

Precisamos separar as mudanças potenciais que as tecnologias podem introduzir nas relações e práticas cotidianas, dos modismos passageiros, das exclusões que ainda se mantêm no universo da explosão digital e dos apelos consumistas que inundam os meios de comunicação. Um dos paradoxos da "sociedade do conhecimento" é que, quanto mais vasta a informação potencialmente disponível, mais seletivo é o conhecimento efetivamente útil e necessário para o mundo do trabalho e para a educação das consciências. Esse fato alerta para a necessidade de uma educação realmente crítica e reflexiva tanto dos professores quanto dos alunos na busca da superação da obsolescência e reducionismo dos conhecimentos que circulam na rede

A formação dos professores deve considerar as mediações tecnológicas como decorrentes de processos históricos e sociais tributárias de ecologias cognitivas específicas sempre tendo em vista para quê, para quem e a que tipo de sociedade se referem esses objetos. Na verdade a formação dos sujeitos deve levar a um manejo crítico e autônomo tanto das informações quanto das tecnologias, duas dimensões inseparáveis do conhecimento contemporâneo.

Nesse esforço de problematizar a relação tecnologias e educação cabe trazer o debate para a escola pública que é o espaço educacional possível da maioria das crianças e adolescentes brasileiros. Nessa perspectiva devemos empreender esforços para promover conteúdos que, além dos conhecimentos científicos, facilitem o acesso e a produção de diferentes linguagens- visuais, musicais, poéticas, digitais, com os meios que dispomos, os tradicionais e os "novos", favorecendo canais de expressão e comunicação sem esquecer que a multimídia é também um lugar onde se situam hoje a oralidade a escrita e a memória.

Entendemos a humanização como usufruto estético e cultural, o acesso aos produtos da cultura humana em sua história, além de uma compreensão mais clara e tomada de posição frente à realidade. Apropriamo-nos da utopia marxista que apregoa a passagem do reino da necessidade para o reino da liberdade pelo acesso aos bens materiais e espirituais a que todos temos direito, para afirmar e indagar ao mesmo tempo: que possibilidades (e limites) de humanização essas tecnologias/meios comportam na realização das potencialidades humanas para além da passividade e submissão ao consumo promovido pelas demandas do mercado capitalista globalizado? Essa é uma questão que deve permanecer no horizonte tanto da formação quanto da atuação docente. 


\section{Referências}

ADORNO, Teodor. Sobre música popular. In: COHN, G. (Org.). Theodor Adorno Sociologia. São Paulo: Ática, 1986. p. 115-146. (Coleção Grandes Cientistas Sociais). Terra, 1995.

Educação e emancipação. Tradução de Wolfgang Leo Maar. São Paulo: Paz e

BARRETO, Raquel, Goulart Formação de professores, tecnologias e linguagens mapeando velhos e novos (des)encontros. São Paulo: Edições Loyola, 2002.

BAUMGARTEN, Maíra. Tecnologia. In: CATTANI, Antônio David; HOLZMANN, Lorena. Dicionário de trabalho e tecnologia. Porto Alegre: Editora da UFRGS, 2006.

BELLONI, Maria Luiza. O papel da televisão no processo de socialização. Série Sociologia Brasília, $\mathrm{n}^{\circ}$ 89, Departamento de Sociologia Universidade de Brasília (UnB) julho/1992.

BRASIL. Conselho Nacional de Educação. Diretrizes Curriculares Nacionais para o Curso de Pedagogia, Brasília, 16 de maio de 2006, Diário Oficial da União, Seção 1, p. 11. 2006. Disponível em http://portal.mec.gov.br/cne/arquivos/pdf/pcp05_05.pdf

Acesso em: 30de novembro de 2012.

CANCLINI, Nestor Garcia. Leitores, espectadores e internautas. São Paulo: Iluminuras, 2008.

DUARTE, Newton. As pedagogias do " aprender a aprender" e algumas ilusões da assim chamada sociedade do conhecimento. Revista Brasileira de Educação, no 18Set/Out/Nov/Dez 2001, p.1-6.

Disponível em: http://www.anped.org.br/rbe/rbedigital/rbde18/rbde18 05 newton_duarte.pdf

Acesso em 10 de agosto de 2013.

Concepções afirmativas e negativas sobre o ato de ensinar. Cadernos CEDES v. 19 n. 44, p.1-6. Campinas Abr. 1998.

FERRÉS, Joan. A pedagogia dos meios audiovisuais e pedagogia com os meios audiovisuais. In: SANCHO, Juana M. (org.). Para uma tecnologia educacional. Porto Alegre: Artes Médicas, 1998.

HORKHEIMER, Max.; ADORNO, Theodor. A indústria cultural - o iluminismo como mistificação das massas. In LIMA, L. C. Teoria da Cultura de Massa, 3. ed. Rio de Janeiro: Paz e Terra, 1982, p. 159-204.

KERCKHOVE, Derrick de. A pele da cultura - Uma investigação sobre a nova realidade eletrônica . Santa Maria da Feira: Relógio D'Água Editores, 1997.

LÉVY, Pierre. As tecnologias da inteligência - o futuro do pensamento na era da informática. Rio de Janeiro: Editora 34, 1993.

LUKÁCZ, George . Ontologia do ser social: Os princípios ontológicos fundamentais de Marx. Trad. Calor Nelson Coutinho. São Paulo: Ciências Humanas, 1979.

MACARIO, Epitácio. Determinações ontológicas da educação: uma leitura à luz da categoria trabalho (UFC). 21 ${ }^{\mathrm{a}}$ Reunião da ANPED 2001. Disponível em: www.anped.org.br/reunioes/24/T0956971638795.DOC. 
Acesso em 07 de maio de 2013.

MACLUHAN, Marshal. Os meios de comunicação como extensões do homem. 5.ed. São Paulo: Cultrix, 1989.

MARKERT, Werner. "Lean Production"- Uma revolução da forma de produção capitalista. A discussão alemã e internacional, sua implementação no Brasil e consequências para a formação profissional. Educação \& Sociedade, n. 49, p. 362- 390, 1994.

TASSIGNY, Mônica Mota. Ética e ontologia em Lukács e o complexo social da educação. Revista Brasileira de Educação: ANPED, n. 25, 82-93, Jan/ Fev /Mar / Abr. Rio de Janeiro -RJ, 2004. Disponível em: http://www.redalyc.org/articulo.oa?id=27502508 Acesso em 25 de maio de 2012.

ROSENFIEL, Cinara Lerrer; NARI, Henrique Caetano.Competência. In: CATTANI, Antonio David; HOLZMANN, Lorena. Dicionário de trabalho e tecnologia. Porto Alegre: Editora da Associados, 2000-a.

SAVIANI, Dermeval. Escola e democracia, 33a . ed. Campinas: Autores Associados, 2000.

Pedagogia histórico-crítica: Primeiras aproximações, $5^{a}$ ed. São Paulo, Autores Associados, 1995.

SUBTIL, Maria José; BELLONI, Maria Luiza. Dos audiovisuais a multimídia:análise histórica das diferentes dimensões de uso dos audiovisuais na escola.In:BELLONI, Maria Luiza (org.). A formação na sociedade do espetáculo. São Paulo: Edições Loyola, 2002.

SUBTIL, Maria José Dozza. A apropriação e fruição da música midiática por crianças de quarta série de ensino fundamental. Tese (Doutorado em Engenharia de Produção Mídia e Conhecimento) - Universidade Federal de Santa Catarina, Florianópolis, 2003.

2006.

Música midiática e o gosto musical das crianças. Ponta Grossa: Editora UEPG,

Reflexões sobre arte e indústria cultural. Linhas Críticas, v.14, n.27, p.283-299,

jul./dez.2008. Disponível em

http://seer.bce.unb.br/index.php/linhascriticas/article/viewArticle/1529.

Acesso em 13 de julho de 2013.

Musicas, mídias e escola: relações e contradições evidenciadas por crianças e adolescentes. Educar em revista, Curitiba, n.40, v.2, p.177-194, abr./jun. 2011. Disponível em http://ojs.c3sl.ufpr.br/ojs2/index.php/educar/article/view/16974

Acesso em 15 de julho de 2013

WITTICH, Walter Arno; SCHULLER, Charles,Francis. Recursos audiovisuais na escolar. 2 ed. Rio de Janeiro: Editora Fundo de cultura SA., 1968. 


\section{Notas}

${ }^{1}$ Mestrado em Educação (UEPG) e doutorado em Engenharia de Produção - Mídia e conhecimento (UFSC) Pesquisadora Sênior e professora do Mestrado e Doutorado em Educação da Universidade Estadual de Ponta Grossa. Coordenadora do Grupo de Estudos e Pesquisas em Educação Arte e Comunicação - GEPEAC. Bolsista Pesquisador sênior Fundação Araucária. e-mails mjsubtil@hotmail.com mjsubtil@gmail.com

2 Essas considerações tomam por base as formulações de Pierre Levy no livro "As tecnologias da Inteligência".

3 Neste texto adoraremos também as denominações meios, e mídias em alguns momentos com significados semelhantes de mediação social e pedagógica, como objetos do processo comunicacional na educação sempre condicionando aos determinantes mais amplos da sociedade que interferem no debate educacional. Embora possamos diferenciar esses termos entre si, na educação, historicamente eles são apropriados em sua dimensão de meios didáticos ou mais recentemente mediações entre os conteúdos veiculados na sociedade e os conteúdos propriamente escolares. Com o advento das tecnologias de informação e comunicação (TICs), desde a década de 60, os estudos deslocam-se para os artefatos em si, como referenciado em Mac Luhan (1989). Com as novas TICs a abordagem assume uma dupla dimensão: os conteúdos veiculados (música, jogos, notícias, dados econômicos, política, etc.) e os processos envolvidos ( interação, comunicação em rede - individual e social, ludicidade, etc).

${ }^{4} \mathrm{O}$ link para o acesso ao Portal do professor é:

http://portal.mec.gov.br/index.php?option=com content \&view=article \&id=269\&Itemid=333

${ }^{5}$ Nas Licenciaturas, em especial na Pedagogia, durante várias décadas os Recursos audiovisuais e/ou Técnicas de Ensino possuiam esse caráter instrumental do uso de equipamentos e de técnicas como condição para o adequado encaminhamento das aulas. Nesse treinamento do uso pedagógico dos meios cabe ressaltar o livro Recursos Audiovisuais na escola de Wittich;Schuller (1964) que foi referência durante esse período.

${ }^{6}$ Kerkhove (1997) no livro A pele da cultura, defende a ideia de que os meios eletrônicos são extensões não só do sistema nervoso e do corpo mas também da psicologia humana. Isso quer dizer que as informações midiáticas são processadas pelos sentidos "pressentidos" ou seja pela pele, pelo tato, tal a intensidade da atuação dos estímulos eletrônicos sobre a corporeidade. Isso nos faz pensar sobre os alunos que temos hoje nas salas e aula e nas estratégias de ensino para as relações pedagógicas. Martin-Barbero(2001), Babin, Kouloumdjian (1982) e Greenfield (1988) apresentam novas perspectivas de análise dos audiovisuais em relação aos efeitos sobre os receptores, em especial os mais jovens (Apud SUBTIL, 2003).

Recebido em julho-2013

Aprovado em setembro-2013 